\title{
SPIRITUALITAS UMA BUNGGURU DALAM ARSITEKTUR RUMAH IBADAH GKS JEMAAT WAINGAPU
}

\author{
Herlina Ratu Kenya
}

\begin{abstract}
Spirituality, ethics and traditions are values that originate from one's appreciation of one's existence in relationship with God, others and the universe. Awareness of the identity of God, the meaning of human presence and how the treatment of the universe is a key value for the creation of a harmonious and dignified life. All of these values are universally applicable and timeless. Spirituality, ethics and tradition are not always revealed verbally or through the actions of a person but can also be visualized through cultural symbols. Customary house is one element of culture that is used as a medium of delivery of value by people or communities in a particular place. Through his traditional house, The people of Sumba visualize the values of spirituality, ethics and traditions such as fellowship, harmony, living together in diversity and living as families, which are the driving force for a life responsibleto God, neighbor and universe. In Christianity, the house of worship is a visualization of the values of spirituality, ethics and traditions lived by the local people of God based on their faith. Through the architecture of the house of worship, the people are reminded of the values that must be a compass for his life both personally and communally so that his life is meaningful. Meaning of life is evident through the works that nurtured and celebrate life together without being hampered by the differences.
\end{abstract}

Keywords: Traditional (Ethnic) House, Spirituality, Ethics and Tradition, Uma Bungguru, Inclusiveness and Harmony

\begin{abstract}
Abstrak
Spiritualitas, etika dan tradisi merupakan nilai yang bersumber pada penghayatan seseorang akan eksistensinya dalam relasi dengan Tuhan, sesama dan alam semesta. Kesadaran akan identitas Tuhan, pemaknaan akan kehadiran manusia serta bagaimana perlakuan terhadap alam semesta merupakan nilai kunci bagi terciptanya kehidupan yang harmoni dan bermartabat. Semua nilai ini berlaku secara universal dan tidak lekang oleh waktu. Spritualitas, etika dan tradisi tidak selalu terungkap secara verbal atau melalui perbuatan seseorang tetapi juga dapat tervisualisasikan lewat simbol-simbol budaya. Rumah adat merupakan salah satu unsure budaya yang digunakan sebagai media penyampaian nilai oleh orang atau masyarakat di suatu tempat tertentu. Melalui rumah adatnya, orang (masyarakat) Sumba memvisualisasikan nilai spiritualitas, etika dan tradisi seperti persekutuan, harmoni, hidup bersama dalam keragaman dan hidup sebagai keluarga, yang merupakan motor penggerak bagi kehidupan yang bertanggungjawab terhadapTuhan, sesama dan alam semesta. Dalam kekristenan, rumah ibadah merupakan visualisasi dari nilai spiritualitas, etika dan tradisi yang dihayati umat Tuhan setempat berdasarkan imannya. Melalui arsitektur rumah ibadah, umat diingatkan akan nilai-nilai yang mesti menjadi kompas bagi hidupnya baik secara personal maupun komunal sehingga
\end{abstract}


hidupnya bermakna. Pemaknaan hidup itu terbukti melalui karya-karya yang merawat dan merayakan kehidupan bersama tanpa terhambat oleh perbedaan yang ada.

Kata Kunci: Rumah Adat, Rumah Ibadah, Spiritualitas, Etika danTradisi, Uma Bungguru, Inklusif dan Harmoni

\section{A. Pengantar}

Sejarah masuknya kekristenan ke Indonesia telah memperlihatkan kepada kita pengaruh etnosentrisme yang sangat kuat. Budaya Indonesia dipandang negatif dan berbahaya bagi iman Kristen sehingga semua unsurnya perlu dihapuskan dan diganti oleh budaya baru dari Eropa sebagai budaya Kristen. Hal ini juga telah menjadi bagian dari pengalaman masyarakat Sumba ketika Injil dibawa kesana oleh lembaga Zending Belanda. Mulai dari bagaimana cara berpakaian, pola hidup, gaya makan sampai kepada ritus-ritus yang terkait religius dan sosial harus berganti dengan pola Belanda pada waktu itu yang dianggap mulia dan bahkan diakui sebagai perintah Tuhan. Melawan budaya Belanda berarti sama dengan melawan perintah Tuhan. Para zendeling memandang dirinya sebagai subyek sedangkan Sumba dan adat istiadatnya merupakan obyek yang mesti ditransformasi. ${ }^{1}$

Gereja Kristen Sumba (GKS) merupakan hasil pekabaran Injil Zending Belanda. Kenyataan ini sudah tentu sangat berpengaruh terhadap seluruh corak hidup bergereja mulai dari segi arsitektur rumah ibadah, pola peribadahan, pola pemerintahan gereja yang diatur melalui tata gereja sampai pada pengajarannya sejak dulu hingga masa sekarang. Memang mesti diakui bahwa telah terjadi juga penyesuaian dan pembaharuan dalam berbagai hal sebagai akibat dari berjumpanya kekristenan Eropa dengan spiritualitas, etika dan tradisi masyarakat di Sumba. Hasil-hasil perjumpaan itu dapat dielaborasi untuk menjadi tulisan yang menarik tentang dinamika kehidupan bergereja di GKS. Namun saya membatasi tulisan ini hanya pada soal arsitektur rumah ibadah saja. Fokusnya pada arsitektur rumah ibadah di Gereja Kristen Sumba Jemaat Waingapu (selanjutnya GKS Waingapu).

Topik ini menjadi menarik karena dari segi arsitektur, model rumah ibadah GKS Waingapu berbeda dengan keseluruhan bangunan rumah ibadah di Sumba. Rumah ibadah di Sumba secara keseluruhan mengikuti model rumah ibadah dari Belanda. Bentuk bangunan gereja yang lazim di Sumba adalah persegi panjang, 
sedangkan arsitektur rumah ibadah Jemaat ini berbeda yakni bangunan berbentuk persegilima. Dari model arsitektur yang unik ini, saya mencoba menggali untuk menemukan nilai spiritualitas yang terkandung di dalamnya. Nilai-nilai spritualitas, etika dan tradisi seperti apakah yang hendak divisualisasikan oleh orang Kristen di Waingapu melalui arsitektur rumah ibadah ini? Sejauh mana nilai-nilai tersebut sejalan dengan nilai spiritualitas, etika dan tradisi masyarakat Sumba yang terkandung dalam rumah adat Sumba yang telah diabaikan bahkan digerus oleh pengaruh etnosentrisme pada masa lampau, walaupun dari arsitekturnya rumah ibadah ini berbeda dengan arsitektur rumah adat Sumba.

Catatan Sejarah mengenai berdirinya Jemaat ini belum pernah dituliskan dalam bentuk dokumen resmi karena itu data yang disajikan dalam tulisan ini diperoleh dengan mengandalkan wawancara terhadap keluarga tokoh-tokoh warga jemaat yang merupakan bagian dari pelaku sejarah pada masa itu.Berdasarkan penuturan para pelaku sejarah ini, butiran-butiran nilai yang senada dengan nilai spiritualitas, etika dan tradisi masyarakat Sumba dikemukakan. Dengan begitu, tulisan ini dapat juga menjadi rujukan sebagai wadah yang menyimpan catatancatatan sejarah berdirinya GKS Jemaat Waingapu.

\section{B. Sejarah Singkat GKS Jemaat Waingapu}

GKS Waingapu menjadi jemaat yang berdiri sendiri pada tanggal 5 April $1931 .^{2}$ Sebelumnya jemaat ini merupakan bagian dari wilayah pelayanan GKS Payeti. Jemaat ini terletak di wilayah administrasi kota Waingapu dan memiliki warga yang heterogen etnis dan budaya. Heterogenitas ini terjadi karena wilayah ini merupakan pusat perdagangan dan dekat laut dimana terdapat tempat yang dijadikan semacam pelabuhan rakyat. Di Jemaat ini hidup bersama orang dari suku Sumba, Sabu, Ambon, Rote, Alor, Timor dan suku-suku lainnya.

Jemaat ini merupakan salah satu dari beberapa Jemaat hasil pekabaran Injil para zendeling di Sumba. Ketika para zendeling diutus ke Sumba, pada awalnya mereka tidak diterima oleh orang Sumba. Th. van den End menulis demikian: selama masa 1881 - 1892, para zendeling tidak berhasil menetap di tengah-tengah orang Sumba. Mereka diam di tengah orang Sabu di Melolo dan di Waingapu, atau di antara penduduk campuran di Waingapu. ${ }^{3}$ Catatan tersebut dibenarkan oleh kenyataan bahwa dalam wilayah pelayanan di Jemaat ini terdapat lingkungan yang 
dinamai Kampung Sabu yang letaknya sangat dekat dengan lokasi gedung ibadah GKS Waingapu. Bila informasi sejarah ini didalami maka dapat ditemukan asal usul jemaat ini. Sangat mungkin Jemaat ini terbentuk dari orang-orang Sabu yang makin banyak berdatangan ke Kambaniru dan Melolo dalam kurun waktu 19 tahun yang selanjutnya melalui relasi sosial dengan orang dari etnis lain akhirnya menetap di kota Waingapu. Dugaan ini dikuatkan oleh fakta sejarah di mana adanya guru dari luar Sumba yang mengajar pada sekolah rakyat di Waingapu. ${ }^{4}$

Pada masa itu, Sumba merupakan wilayah yang dimasuki oleh tiga lembaga zending Belanda yakni Nederlands Gereformeerde Zendings Vereninging (NGZV), Zending der Christelijke Gereformeerde Kerk (ZChGK) dan Zending van de Gereformeerde Kerken in Nederland (ZGKN) secara bergantian sesuai dengan pergolakan sejarah gereja di Belanda. ${ }^{5}$ Kehidupan bergereja di Sumba diatur oleh ketiga lembaga Zending ini. Dengan demikian ketika Jemaat Waingapu berdiri sendiri bukan dalam pengertian mandiri secara administratif atau lepas dari intervensi Zending tetapi lebih kepada pengertian pembagian wilayah pelayanan berdasarkan aturan Zending sehingga memudahkan pengaturan baik dari segi ketenagaan Pendeta maupun keuangan. Pada masa-masa itu, jemaat-jemaat yang ada merupakan jemaat Zending. Setelah waktu yang panjang, GKS baru menjadi gereja yang berdiri sendiri secara administratif karena telah dinilai mampu bertanggung jawab dalam memimpin gerejanya pada 15 Januari $1947 .{ }^{6}$

Pada tahun 1940-an, lembaga Zending mengutus seorang Pendeta dari suku Sabu yakni Pdt S.H. Dara untuk bertugas sebagai Pendeta di Jemaat Waingapu. Berdasarkan kebutuhan Jemaat untuk beribadah maka Pendeta Dara membangun gedung ibadah dengan model persegi panjang, atap sirap, dinding tembok dan lantai ubin. Karena perkembangan jumlah warga gereja maka kemudian gedung ini direnovasi menjadi gedung yang ukurannya jauh lebih besar tetapi model sebelumnya tetap dipertahankan.

Pada tahun 1960-an, di Jemaat ini telah bertambah dua orang tenaga Pendeta yaitu Pendeta Nicolas He, M.Th dan Pendeta Y.W. Ratu menggantikan Pendeta S.H.Dara yang telah memasuki masa pensiun. Pada tahun 1970, seorang tenaga ahli bangunan bernama Tuan Wynia dikirim dari Belanda ke Sumba untuk membantu GKS dalam membangun rumah sakit Kristen Lindimara di Payeti. ${ }^{7}$ 
Dalam interaksi yang terjalin diantara Pendeta Nico dengan Tuan Wynia lahirlah gagasan untuk membangun gedung ibadah dengan model yang berbeda dari gedung-gedung ibadah yang telah ada di Sumba. Pada tahun 1972, dibawah gagasan dan rancangan Tuan Wynia, Pendeta Nico dan Pendeta Ratu membawa umat yang beragam suku itu bersatu dalam semangat persekutuan sehingga akhirnya benar-benar dapat membangun rumah ibadah yang sampai sekarang masih dipergunakan.Panitia pembangunan segera dibentuk dengan personalia sebagai berikut: ketua: Umbu Remu Samapaty, sekretaris satu: Umbu Ngelu Dedi, sekretaris dua: Yosina Siahainenia dan bendahara: Alex Supusepa.Rancangan dalam bentuk sketsa diberikan oleh Tuan Wynia kepada panitia dan dengan bantuan bapak Z.B.Taulo yang juga memiliki pengetahuan soal bangunan, pekerjaan membangun dikerjakan oleh panitia dan umat yang saling bahumembahu. ${ }^{8}$ Pada tahun 1974 Tuan Wynia sudah kembali ke Belanda namun Pendeta Nico terus membangun komunikasi dengannya untuk menginformasikan perkembangan pengerjaan rumah ibadah.

Proses pengerjaan rumah ibadah ini memakan waktu cukup lama (kira-kira enam tahun) sehingga baru dapat diresmikan kira-kira tahun 1978. Tuan Wynia baru dapat melihat rumah ibadah ini secara langsung ketika tahun 1990 dia dan isteri berkesempatan berkunjung ke Waingapu saat sidang sinode GKS yang ke-32 berlangsung di Jemaat ini. Biasanya arsitektur rumah ibadah memiliki model yang sama yakni persegi panjang seperti yang ada di Belanda, namun oleh tuan Wynia model rumah ibadah GKS Waingapu dirancang dengan model persegilima sehingga dari luar bila dilihat secara utuh, membbentuk huruf $\mathrm{W}$ dan di bagian dalam membentuk ruangan setengah lingkaran.

\section{Rumah ibadah GKS Waingapu: tampak luar depan}

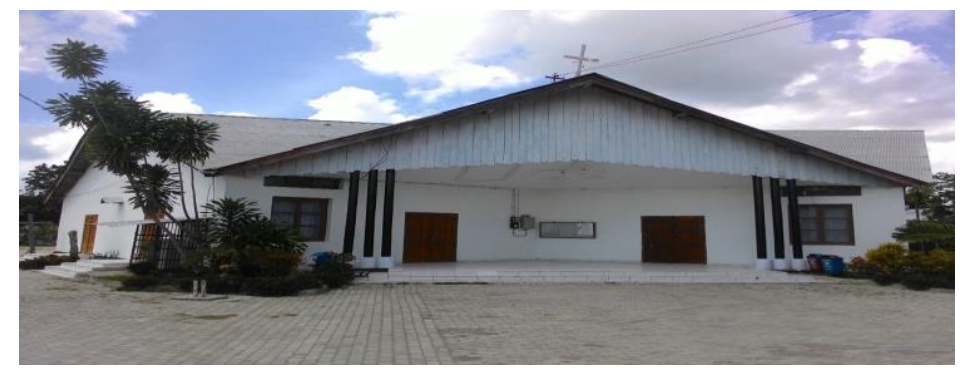

Dari penuturan beberapa warga gereja yang terlibat langsung dalam pembangunan pada waktu itu, diperoleh informasi bahwa untuk membangun 
gedung ibadah ini, umat benar-benar diberi ruang untuk berpartisipasi. Secara bergotong-royong umat mengumpulkan material berupa batu dan pasir, sedangkan kayu, semen, paku dan keperluan untuk atap berupa sirap telah disediakan oleh gereja dari bantuan yang dikirim dari Belanda.Material batu dikumpulkan oleh umat dari satu tempat yang bernama Kanatang (kira-kira $25 \mathrm{~km}$ jaraknya dari Waingapu) dan pasir dikumpulkan dari dua tempat yakni Manubara dan Padadita (kira-kira berjarak 1- $3 \mathrm{~km}$ dari Waingapu). ${ }^{9}$

Secara fisik, gedung ibadah GKS Waingapu dapat digambarkan sebagai berikut: model gedung persegilima, dengan enam tiang di luar yang berfungsi ganda yaitu sebagai penyangga emper dan media simbolik, tiga di sebelah kanan dan tiga di sebelah kiri. Memiliki 8 buah pintu, yakni dua buah di depan, dua buah di samping kiri, dua buah di samping kanan, satu buah di dalam yang menghubungkan ruangan ibadah dengan ruang konsistori dan satu buah di belakang sebagai pintu masuk atau keluar ke dalam dan dari konsistori. Jendela terdiri dari 14 buah yaitu dua buah di depan dan di masing-masing sisi kiri dan kanan terdapat empat buah terletak di ruangan ibadah dan empat buah lainnya di konsistori. Lantai terbuat dari ubin. Bangunan terdiri dari dua ruangan yakni ruangan ibadah dan konsistori. Ruangan ibadah berbentuk setengah lingkaran dengan hanya terdapat satu tiang tetapi bukan dalam fungsi sebagai penyangga atap melainkan bermakna simbolik, sedangkan konsistori berbentuk persegi empat. Mimbar berada di tengah ruangan yang lantainya dibuat lebih tinggi dari lantai yang diduduki umat. Langit-langit tepat di atas mimbar dicat berwarna-warni. ${ }^{10}$ Kapasitas ruangan dapat menampung $750-800$ orang. ${ }^{11}$

\section{Letak tiang tunggal dalam ruangan ibadah.}

\section{Letak mimbar di tengah - depan ruangan ibadah} dengan lantai yang lebih tinggi

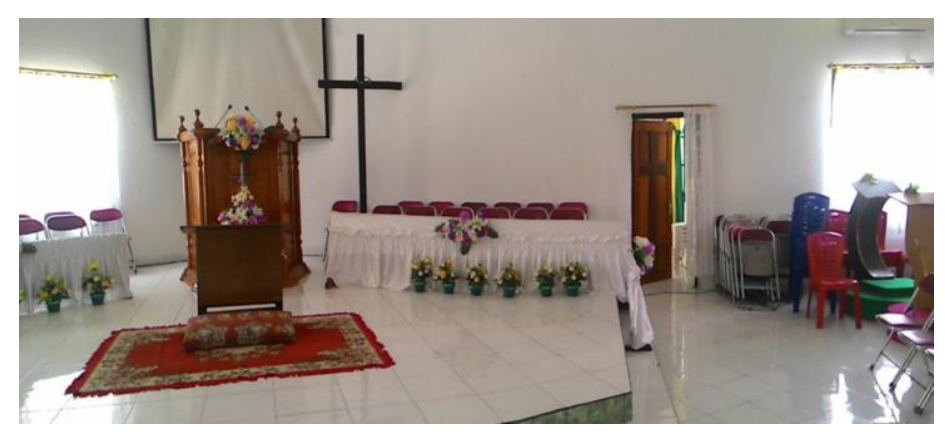




\section{Rumah Adat Sumba}

Orang Sumba memiliki konsep dan pandangan sendiri mengenai rumah atau uma, karena itu mereka mengklasifikasikan rumah dalam beberapa jenis sesuai fungsinya.Tiga macam rumah berdasarkan fungsinya yaitu "uma pangia pandaungu" untuk ditempati setiap hari, "uma njangga” dibuat untuk menjaga kebun atau disebut juga rumah kebun dan "uma bungguru” (bahasa Sumba Timur: Kambera, artinya rumah berkumpul) uma kalada (di Sumba Barat: rumah besar) digunakan sebagai tempat berkumpul atau berhimpun untuk kepentingan ritus religius, pertemuan keluarga dan musyawarah adat dari seluruh anggota kabisu ${ }^{12}$ guna menyelesaikan masalah-masalah yang dihadapi bersama. ${ }^{13}$ Menurut Irene Umbu Lolo, istilah uma bungguru yang dikenakan kepada rumah adat lahir dari fungsi dan nilai filosofinya sebagai tempat berkumpul untuk pertemuan keluarga, mengadakan musyawarah adat atau pemujaan terhadap Yang Ilahi. ${ }^{14}$

Konsep ini bermula dari dari kebiasaan nenek moyang orang Sumba ketika untuk pertama kali datang dan menetap di Sumba. Setelah para leluhur memasuki Sumba, mereka segera membangun pemukiman yang disebut paraingu (kampung) sebagai tempat bagi keluarga mereka. ${ }^{15}$ Dalam paraingu itu, didirikan rumahrumah sesuai kebutuhan. Biasanya yang tinggal dalam satu paraingu adalah keluarga. Jarak paraingu yang satu dengan yang lainnya cukup jauh. Dalam perkembangan selanjutnya, dengan bertambahnya jumlah keluarga dan ditambah lagi dengan jumlah penduduk yang makin banyak memasuki Sumba maka paraingu menjadi sempit sehingga anggota keluarga yang lain diizinkan untuk membangun rumah di luar paraingu. Walaupun demikian mereka tetap terikat sebagai anggota paraingu dan sebagai tanda ikatan itu maka pada saat upacara kematian, perkawinan dan ritus-ritus keagamaan mereka harus kembali berkumpul dengan keluarga mereka dalam paraingu asalnya. ${ }^{16}$

Fungsi rumah tinggal dan rumah kebun bersifat pribadi sedangkan rumah berhimpun (rumah adat) bersifat umum. Rumah adat terletak dalam paraingu. Di uma pangia pandaungu dan uma njangga, masing-masing orang melakukan kegiatan kehidupan yang terkait dengan pemenuhan kebutuhan sendiri tetapi di uma bungguru adalah waktu untuk melebur dalam kepentingan bersama seluruh klen. Dari penjelasan ini, dapat dimengerti bahwa orang Sumba hidup dalam tradisi 
keluar dari rumah tempat mereka tinggal sehari-hari atau rumah untuk bekerja pada waktu-waktu tertentu kemudian berhimpun dengan yang lainnya di uma bungguru guna melakukan hal-hal yang terkait dengan ritus religius atau sosial.Rumah adat atau uma bungguru merupakan simbol panggilan bersekutu bagi kepentingan komunal dan penyembahan terhadap Sang Ilahi karena itu uma bungguru memiliki nilai sakral dan magis bagi anggota paraingu. ${ }^{17}$

Rumah adat Sumba berbentuk persegi empat dengan tiang-tiang yang tinggi dan pada bagian atap terdapat menara. Dengan konstruksi yang demikian maka rumah adat Sumba terdiri dari tiga bagian yakni bagian bawah, bagian tengah dan atas. Tiga bagian ini mewakili fungsi simbolis terkait dengan kosmologi dalam pandangan orang Sumba. Bagian bawah merupakan tempat binatang peliharaan seperti ayam, anjing, babi, kuda dan kerbau, sekaligus merupakan simbol dari "alam bawah" dimana hidup roh-roh halus. ${ }^{18}$ Bagian tengah merupakan tempat manusia dan aktifitas kehidupan manusia dan bagian atas merupakan tempat dimana bahan makanan dan benda-benda sakral yang dipergunakan untuk penyembahan terhadap Marapu diletakkan. Bagian atas ini juga merupakan simbol dari "alam atas" dimana para leluhur dan Yang Ilahi berdiam dan dari sana menurunkan berkat bagi kehidupan ciptaan-Nya. Ketiga alam ini mesti dijaga keseimbangan relasinya oleh manusia agar harmonis sehingga membawa kebaikan. Apabila diabaikan maka kehidupan manusia dan alam terganggu sehingga membawa dampak buruk. ${ }^{19}$

\section{Rumah Adat Sumba}

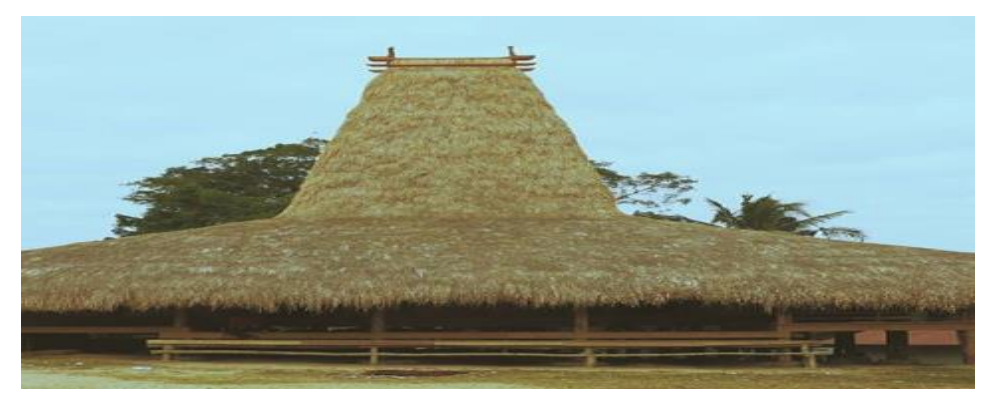

Secara singkat, proses pembangunan rumah adat Sumba dapat digambarkan demikian: diawali dengan pemasangan empat tiang utama, salah satu diantaranya adalah tiang doa. Fungsi utama dari empat tiang ini adalah sebagai kerangka dasar dari rumah. Tiang doa inilah yang dipasang terlebih dahulu sebagai patokan untuk pemasangan tiga tiang lainnya. Pada empat tiang utama ini dipasang balok-balok 
besar sebagai penahan lantai panggung rumah. Pekerjaan dilanjutkan dengan memasang kayu penahan bagian menara disusul dengan pemasangan dua belas tiang keliling yang fungsinya untuk menahan atap rumah. Setelah kerangka rumah selesai dipasang dan diatapin, selanjutnya adalah memasang dinding keliling yang terbuat dari anyaman bambu. ${ }^{20}$

Terdapat tiga buah pintu, dua terletak di bagian depan yakni satu di sebelah kanan dan yang satunya lagi di sebelah kiri, dan satu lagi terletak di bagian belakang. Tahap selanjutnya adalah mengatur bagian dalam rumah. Bagian dalam terdiri dari balai-balai tempat sembahyang dan tempat musyawarah, tempat menyimpan perlengkapan sembahyang, tempat menyimpan barang keramat, balaibalai tempat tamu, kamar tidur, dapur, kamar tempat menyiapkan dan membagikan makanan, balai-balai dekat tungku arah samping tempat sembahyang dan balaibalai bagian bawah dekat pintu belakang. ${ }^{21}$

Sebelum kekristenan masuk ke Sumba, masyarakat Sumba telah memiliki sistem kepercayaan terhadap realitas Yang Ilahi sehingga telah terbentuk agama suku disana yaitu Marapu. Pemujaan terhadap Yang Ilahi diikuti oleh seluruh kabisu (klen) yang pelaksanaannya berlangsung di rumah adat (uma bungguru) dipimpin oleh imam yang disebut Rato. Di tiang doa, Rato mengajukan permohonan kepada Yang Ilahi baik personal maupun komunal. Melalui Rato, umat menerima pernyataan Ilahi terkait dengan pergumulan yang disampaikan baik yang bersifat pribadi maupun komunal. Pernyataan Ilahi ini berdampak pada tanggung jawab terhadap kehidupan pribadi, sesama dan alam sebagai wujud tanggung jawab terhadap Yang Ilahi.

Irene dalam tesisnya mengungkapkan hasil penelitiannya bahwa sampai dengan masa ini di Sumba belum ada arsitektur rumah ibadah yang mengambil model rumah adat Sumba. Pengaruh etnosentrisme terlihat di sini. Pada saat kekristenan masuk ke Sumba, konsep dan pemikiran orang Sumba mengenai uma bungguru tidak mendapat perhatian para zendeling. Para zendeling memiliki pandangan yang negatif terhadap rumah orang Sumba. ${ }^{22}$

Itulah sebabnya arsitektur rumah ibadah selalu mengikuti arsitektur di Belanda. Arsitektur rumah ibadah di Belanda mengikuti model abad pertengan dengan model memanjang dari depan ke belakang. Model seperti itulah yang 
dikembangkan di Sumba lalu ditambah menara di bagian depan untuk menunjukkan ciri khas Sumba.

Walau pun demikian, hal ini tidak berarti bahwa nila-nilai spiritual, etika dan tradisi yang terkandung dalam rumah adat Sumba itu telah ditinggalkan atau tidak lagi dihidupi oleh masyarakat di Sumba.

\section{Spiritualitas Uma Bungguru Dalam Arsitektur Rumah Ibadah GKS Waingapu.}

Salah seorang sekretaris panitia pembangunan gedung ibadah di Jemaat ini waktu itu yakni Ibu Yosina Siahainenia mengatakan bahwa dalam percakapan dengan panitia, Tuan Wynia menjelaskan beberapa hal tentang model rumah ibadah yang akan dibangun. Penjelasannya demikian: bila dilihat dari luar, keseluruhan bangunan membentuk huruf W. Huruf ini bukanlah inisial dari namanya sebagai pencetus ide pembangunan gedung ini melainkan menunjuk kepada nama kota Waingapu sebagai tempat dimana jemaat ini hidup. Terdapat enam tiang di emper dan satu tiang di dalam. Tiang-tiang inimerupakan lambang dari enam hari kerja dan hari Sabat. Mimbar terletak di bagian depan sebagai simbol dari pemberitaan sabda Tuhan, dan langit-langit tepat di atasnya berwarnawarni untuk menunjukkan keragaman dalam Jemaat.

Menurut Stephen Bevans, Teologi tidak mesti bersifat verbal. ${ }^{23}$ Pernyataan Bevans ini menjadi nyata dalam pengalaman GKS Waingapu. Penghayatan tentang nilai spiritualitas uma bungguru yang tidak bersifat verbal itu diungkapkan melalui arsitektur rumah ibadah GKS Waingapu walaupun secara fisik bentuknya berbeda dengan rumah adat Sumba. Melalui arsitektur rumah ibadahnya, secara non verbal umat di Jemaat ini mengekspresikan teologi atau penghayatan imannya atas siapaTuhan dan bagaimana tanggung jawab mereka berkaitan dengan sesama dan lingkungan. Ungkapan non verbal tentang ciri persekutuan yang digerakkan oleh tanggung jawab etis masih menjadi bagian dari kehidupan masyarakat Sumba.Bertolak dari hal ini maka dari penjelasan yang diberikan Tuan Wynia tentang arsitektur rumah ibadah GKS Waingapu seperti di atas, terdapat beberapa nilai spiritualitas yang sejalan dengan kandungan spiritualitas uma bungguru yang hendak sayakemukakan di sini. Nilai-nilai ini berguna baik bagi personal maupun komunitas dalam relasi dengan Tuhan, sesama dan alam karunia Tuhan. 
Pertama, Waingapu dipandang sebagai tempat pemujaan terhadap Tuhan yang transenden ${ }^{24}$ dan sebagai ranah sejarah yang mencatat karya Tuhan. Pengakuan ini meliputi baik dimensi universal dari kehadiran masyarakat dan pulau Sumba maupun secara khusus pemaknaan terhadap keberadaan umat Kristen dan Jemaat Waingapu. Maksud dari dua model pemaknaan ini menolong umat agar mendengar undangan Allah untuk terlibat dalam karya-Nya dari masa ke masa. Dengan begitu Waingapu menjadi tempat dimana Tuhan sebagai Pencipta dan umat menjadi rekan kerja demi membawa kesejahteraan dan kebaikan bagi manusia dan dunia.

Dalam terang undangan Allah di atas, kisah lahirnya nama Waingapu bagi wilayah ini berdasarkan penuturan beberapa orang Sumba patut diperhatikan. Untuk hal ini ada tiga versi cerita. Versi pertama, berasal dari dua kata dalam bahasa Sumba yaitu lai yang artinya mau ke mana atau dari mana dan ngapu yang sebenarnya merupakan nama orang. Ngapu ini adalah seorang pedagang dari Lawonda (sekarang wilayah Sumba Tengah) yang berdagang macam-macam barang di sebuah tempat dekat laut yang kemudian diberi nama Pasar Lama sampai sekarang. Rupanya dagangan Ngapu telah menarik minat pembeli dari berbagai tempat di Sumba, itu sebabnya jika ada yang bepergian keluar atau kembali ke kampung dan ditanya hendak kemana atau dari mana, orang tersebut akan mengatakan lai-ngapu yang secara hurufiah dapat diartikan mau ke tempatnya atau dari tempatnya Ngapu sang pedagang tadi. Tujuannya sudah tentu untuk membeli barang dagangan yang dijual oleh Ngapu. Dekat pasar itu, terdapat rumah seorang Arab bernama Hamid Fadaq yang datang berdagang kesana dan kemudian berdomisili tetap di daerah itu. Di belakang rumah Hamid Fadaq, tumbuh pohon yang sangat besar dan di suatu waktu menurut cerita, dekat pohon itu muncul mata air. $^{25}$ Kemunculan mata air ini dikemudian hari mengubah kata lai menjadi wai yang dalam bahasa Sumba berarti air sehingga penyebutannya menjadi waingapu dan bukan lagi lai-ngapu. ${ }^{26}$

Menurut versi kedua, nama itu berasal dari dua kata yakni wai (air) dan ngapu dari kata тари (ilalang atau rumput liar). Di mana persisnya letak air ini tidak diketahui namun air dan ilalang merupakan lambang dari kemakmuran sehingga Sumba Timur dikenal dengan motto Matawai Amahu Pada Njara 
Hammu" (arti hurufiahnya mata air emas dan padang rumput kuda yang baik). ${ }^{27}$ Sedangkan menurut menurut versi ketiga, nama ini berasal dari dua kata yaitu wai (artinya air) dan ngapu yakni nama seorang penjual garam di Manubara.

Di balik kisah-kisah di atas, terjalin pengalaman kehidupan banyak orang dan makhluk hidup lainnya mulai dari mata air yang muncul dekat pohon di dekat rumah Hamid Fadaq dan jerih lelah Ngapu dalam berdagang menurut versi cerita pertama, atau mata air dan padang rumput dalam versi kedua, maupun air dan penjual garam dalam versi ketiga.Kisah-kisah ini merupakan sebagian dari banyak cerita yang hendak menegaskan kebenaran tentang Waingapu sebagai tempat kehadiran dan karya Allah yang mencipta dan memelihara kehidupan. Disana Allah menyediakan air, laut, kuda, padang rumput dan berbagai ciptaan lainnya. Allah menyerahkan semua ciptaan itu kepada manusia untuk dipelihara, dikembangkan dan dikelola demi berkelanjutannya kehidupan ciptaan-Nya.Waingapu mengingatkan umat pada undangan Allah untuk meneruskan karya kehidupan yang telah dianugerahkan kepada mereka.

Kedua, makna simbolik dari tiang-tiang di luar dan di dalam dalam arsitektur rumah ibadah GKS Waingapu merupakan ungkapan dari nilai persekutuan seperti yang dihidupi oleh masyarakat Sumba yang digambarkan melalui fungsi uma bungguru. Masing-masing diberikan waktu enam hari oleh Tuhan untuk bertanggung jawab atas kehidupan pribadi dan keluarga melalui setiap pekerjaan dan perannya di segala bidang. Kepada manusia diberi waktu untuk mengurus kepentingan-kepentingan yang bersifat pribadi. Tetapi Tuhan juga mengundang umat untuk memasuki persekutuan dengan-Nya dan persekutuan dengan sesama melalui ibadah formal pada hari Minggu. Persekutuan ini bermakna ganda yakni secara vertikal umat membangun hubungan dengan Tuhan dan secara horizontal umat membangun persekutuan dengan sesama. Melalui persekutuan dengan Tuhan umat memperoleh spirit baru untuk mengerjakan tugas-tugasnya sebagai wujud iman yang akan dipertanggungjawabkan lagi kepada Tuhan ${ }^{28}$ sedangkan melalui persekutuan dengan sesama, umat kembali diingatkan akan tanggung jawabnya dalam membangun kehidupan bersama yang harmonis dan bermartabat. Manusia diminta untuk memberikan waktu demi membina persekutuan dengan Tuhan dan dengan sesama.Nilai sakralitas dalam persekutuan di uma bungguru menurut tradisi Marapu di sini ditentukan oleh perjumpaan umat 
dengan Tuhan yang menguduskannya untuk melakukan tugas-tugas demi kebaikan, keadilan, solidaritas dan perjuangan-perjuangan bagi kemaslahatan bersama.

Pada masa lampau, nilai persekutuan yang dihidupi masyarakat Sumba diperhadapkan pada tantangan tersendiri. Jarak rumah yang sangat jauh antara satu dengan yang lainnya, ditambah lagi dengan kondisi geografis yang berbukit-bukit dan jalanan yang turun naik menjadi tantangan tersendiri. Namun masyarakat Sumba tetap konsisten memelihara tradisi tersebut. Mereka keluar dari rumahnya masing-masing pada waktu-waktu yang telah disepakati bersama untuk berkumpul di uma bungguru demi terbangunnya relasi vertikal dan horizontal.Kedua relasi ini dinilai penting bagi kebaikan hidup mereka.

Di era yang makin global dengan tingkat perubahan nilai yang sangat besar seperti sekarang ini, masyarakat Sumba berhadapan dengan tantangan dimana orang makin sibuk dengan diri dan dunianya sendiri, sehingga persekutuan sebagai nilai spiritual dan etika makin terkikis tergantikan oleh persekutuan di dunia maya hasil ciptaan media. ${ }^{29}$ Perjumpaan yang bersifat face to face mulai tersingkirkan. Pola relasi menjadi sangat mekanistis. Kemajuan ilmu pengetahuan dan teknologi yang menawarkan kehidupan serba mudah, cepat dan instan dapat menciptakan kemandirian tanpa batas sehingga orang dengan mudah terdorong kepada perasaan tidak lagi merasa perlu berelasi dengan Tuhan dan dengan sesama. Orang merasa dapat mengurus dirinya sendiri tanpa bantuan orang lain. Manusia menjadi sangat individualistik dan mudah mengalami alienasi. Padahal nilai dan makna kemanusiaan justru terletak pada kemampuan membangun relasi dengan Tuhan dan sesama.

Ketiga, letak mimbar yang sentral yakni di depan ruangan yang berbentuk setengah lingkaran. Pada satu sisi, penataan ini mewakili pandangan GKS sebagai gereja yang beraliran Calvinis dengan corak teologi reformasi dimana pemberitaan sabda merupakan puncak dari seluruh ibadah, ${ }^{30}$ dan pada sisi yang lain spiritualitas Firman yang tersamar dalam tradisi religius Marapu semakin jelas terlihat di sini. ${ }^{31}$ Dalam keyakinan Marapu, peran Rato dalam pemujaan religius di uma bungguru adalah untuk mencari kehendak Yang Ilahi. Melalui penyataan kehendak (firman) Ilahi yang diterima Rato, Yang Ilahi menyatakan kehadiran-Nya dalam kehidupan umat. Hal serupa ditemukan dalam keyakinan Kristen bahwa firmanadalah bentuk 
imanensi Allah yang menjadi pusat dari seluruh kehidupan umat.Firman yang telah menjadi daging yaitu Yesus Kristus (Yoh 1: 2,14) menjadi pusat dari kehidupan umat. Firman itu adalah Allah yang dekat dengan kehidupan manusia. Allah itu tidak jauh dari kehidupan manusia. Allah bahkan tinggal bersama umat-Nya. Menurut Injil Yoh 14: 6, Firman itu adalah jalan dan kebenaran dan hidup yang menghubungkan umat dengan Bapa. Ketika orientasi dan arah hidup manusia menuju kepada kecenderungan terhadap yang jahat, Sang Firman menunjuk arah yang tepat. Hal ini mesti membentuk perilaku etis umat secara person dan komunal yang diperlihatkan dalam segala peran kehidupan sehingga transformasi masyarakat terjadi. $^{32}$ Perjuangan untuk menciptakan keadilan, menyatakan keberpihakan pada mereka yang miskin dan tertinggal, upaya untuk melestarikan lingkungan, menolak pertambangan emas, pendampingan terhadap mereka yang mengalami kekerasan dalam rumah tangga, menjembatani ketimpangan gender dan berbagai perjuangan lainnya yang bertujuan membebaskan dan memulihkan di Sumba mesti lahir dari penghayatan akan Firman Allah.

Keempat, secara sadar keragaman yang menjadi latarbelakang umatsecara khusus di Jemaat ini dan masyarakat Waingapu secara umum tervisualisasi melalui warna yang bermacam-macam di langit-langit tepat di atas mimbar.Keragaman merupakan karya Allah dan karenanya mesti dipelihara dan dikembangkan oleh umat. Keragaman bila ditempatkan dalam prinsip saling melengkapi akan menghasilkan keindahan seperti warna pelangi yang merupakan tanda janji Allah untuk tidak menghukum dunia lagi dengan air bah dalam kitab Kejadian.Dalam beberapa dekade, keragaman telah menjadi momok yang menakutkan bagi denominasi-denominasi gereja dan agama-agama. Munculnya sikap arogansi dengan klaim kebenaran mutlak merupakan fakta yang lahir dari keragaman agama yang dimaknai secara salah sehingga menyebabkan terkoyaknya nilai-nilai kemanusiaan. Atau kisah perebutan umat antara gereja yang satu dengan gereja yang lainnya. Namun sejatinya keragaman adalah keagungan karya Allah yang mesti melahirkan nilai spiritual dan etika belajar, bekerja dan merayakan hidup bersama sebab Dia ada dalam semua kepelbagaian itu. Tuhan yang ada dalam semua keragaman itu mendorong umat untuk hidup bersama sebagai satu keluarga.

Secara komunal, spriritualitas kesatuan dalam keragaman mendorong GKS Waingapu keluar dari 'rumah'nya sendiri dan meleburkan diri dengan umat dari 
denominasi dan agama lain untuk menghasilkan karya keadilan dan kesejahteraan bersama di Sumba. Tindakan 'keluar' ini bisa diwujudkan dalam berbagai aksi yang makin membongkar sikap eksklusifitas.

Kelima, jumlah jendela dan pintu yang cukup banyak membuat gedung ibadah ini terbuka sehingga sirkulasi udara sangat baik dan menciptakan suasana yang bebas dari suhu udara panas. Model ini sangat cocok bagi Sumba yang beriklim tropis dengan suhu udara yang sangat panas. Desain yang demikian merupakan ungkapan keberpihakan pada alam. Ruangan seperti ini tidak membutuhkan air conditioner (ac). Hidup harmoni dengan alam adalah salah satu nilai spiritualitas yang tervisualisasikan melalui uma bungguru sebagai salah satu kunci kebaikan hidup manusia. Bila manusia mengabaikan harmoni ini maka keseimbangan hidup terganggu dan dengan begitu mendatangkan malapetaka.

\section{E. Refleksi Kritis Atas Nilai Spiritualitas Dalam Realitas Masa Kini.}

Setelah mengemukakan nilai spiritualitas uma bungguru dalam arsitektur rumah ibadah GKS Waingapu, kini penulis tiba pada refleksi kritis atas nilai tersebut dalam pengalaman umat disana masa sekarang baik bagi kehidupan gereja secara internal maupun dalam kehidupan bersama dengan agama-agama lain.

Pada tanggal 5 April 2015, Jemaat ini merayakan ulang tahunnya yang ke 84 tahun. Sungguh suatu perjalanan ziarah yang panjang dimana proses pewarisan nilai-nilai spiritual dan etika terus dilakukan dari generasi ke generasi.Dalam ziarah ini, aksi dan refleksi merupakan keharusan sehingga panggilan gereja menjadi makin relevan dalam konteksnya. Sudah banyak hal sebagai aksi gereja namun dalam pengamatan penulis, masih banyak juga yang tinggal sebagai agenda saja. Program-program pelayanan yang bersifat rutinitas seperti ibadah, pastoral, pekabaran Injil, diakonia, oikumene belum sepenuhnya mencerminkan nilai-nilai spiritualitas dan etika yang tervisualisasi lewat arsitektur rumah ibadah. Pendewasaan umat dalam kultur masyarakat yang makin terambah oleh budaya modern luput dari perhatian gereja. Pembinaan-pembinaan yang bertujuan untuk melatih umat agar dapat memaksimalkan perannya di dunia kerja, politik, ekonomi, kesehatan dan bidang-bidang lainnya belum mendapat lirikan mata gereja. Gereja masih terus bergerak dalam ranah pembangunan rohani dengan kecenderungan mematok jarak dari kehidupan profan. 
Adalah sesuatu yang menggembirakan melihat kenyataan bahwa umat merindukan dan mempertahankan spiritualitas persekutuan ibadah umat dan membangun kesatuan sebagai satu keluarga secara internal. Namun persekutuan dengan agama-agama lain sebagai satu keluarga yang menghasilkan karya bersama belum terpikirkan. Tentu yang saya maksudkan di sini bukan sekedar menjadi anggota FKUB melainkan pembangunan nilai-nilai kekeluargaan lewat proses belajar, bekerja dan merayakan kehidupan bersama.

Berkat globalisasi dan kemajuan ilmu pengetahuan dan teknologi, maka pada masa kini Sumba menjadi rumah bersama yang terbuka. Mobilitas penduduk yang sangat tinggi menyebabkan Sumba sebagai rumah yang heterogen dalam berbagai aspek termasuk pluralitas agama. Dalam situasi yang demikian, spiritualitas, etika dan tradisi uma bungguru dari arsitektur rumah ibadah di GKS Waingapu menjadi nilai yang ramah dan merangkul keberagaman ini. Gereja menjadi rumah bersama bagi semua agama yang melahirkan tanggung jawab bersama untuk merawat dan merayakan kehidupan bersama.

\section{F. Penutup}

Arsitektur rumah ibadah memiliki kandungan nilai spiritual dan etika yang hendak disampaikan. Nilai spiritual ini mesti dihidupi oleh umat sehingga arsitektur rumah ibadah dan kehidupan umat merupakan satu kesatuan sebagai pembawa pesan Allah. Kesatuan yang demikian akan berdampak terhadap pembentukan spiritualitas masyarakat dimana pengabdian terhadap Allah menjadi nyata lewat karya hidup yang memanusiakan manusia dan menghargai kehidupan.

Arsitektur rumah ibadah sebaiknya dibangun berdasarkan nilai-nilai spiritual dan etika yang terkandung dalam budaya lokal sehingga pemujaan terhadap Allah bukanlah sesuatu yang asing melainkan ungkapan syukur yang lahir dari nilai-nilai yang sudah ia hidupi. Kearifan lokal bukanlah budaya tandingan bagi kekristenan melainkan tanda-tanda kehadiran Allah yang harus digali oleh gereja untuk dimunculkan sehingga dapat dipakai sebagai panduan hidup umat. Spiritualitas, etika dan tradisi masyarakat Sumba merupakan pegangan hidup yang baik dalam relasi dengan Tuhan maupun dengan sesama dan alam. Bila hal ini tidak digerus oleh semangat etnosentrisme pada masa lampau maka dapat ditemukan harmoni yang indah sebagai perpaduan nilai Injil dan nilai hidup yang 
dimiliki masyarakat Sumba. Harmoni ini dapat menyumbang kebaikan bagi relasi antar sesama dalam agama yang berbeda maupun kebaikan dalam relasi manusia dengan alam karunia Sang Ilahi.

\section{Catatan akhir:} ${ }^{1}$ John Mansford Prior, Berdiri di Ambang Batas, (Maumere: Penerbit Ledelero, 2004), hlm. 83
${ }^{2}$ Untuk waktu mandirinya jemaat ini terdapat dua informasi yang berbeda. Th. van den End dalam
bukunya mencatat bahwa GKS Jemaat Waingapu didewasakan pada tahun 1932 (lihat Sumber-
Sumber Zending Tentang Gereja Kristen Sumba $1859-1972$, h.42), sedangkan catatan sejarah
singkat Gereja Kristen Sumba pada pedoman acara Pertemuan DGI Wilayah Nusa Tenggara Timur
yang berlangsung di Klasis Waingapu pada tanggal $25-28$ Januari 1984, hlm.16 mencatat bahwa
pada tanggal 5 April 1931 jemaat ini didewasakan. Nampaknya Majelis Jemaat GKS Jemaat
Waingapu menetapkan tanggal mandirinya berdasarkan catatan ini hingga sekarang.

${ }^{3}$ Th. van den End, Sumber-Sumber Zending Tentang Sejarah Gereja Kristen Sumba 1859 - 1972 (Jakarta: BPK Gunung Mulia, 1996), hlm.6

${ }^{4}$ Ibid, hlm.23

${ }_{6}^{5}$ F.D.Wellem, Injil Dan Marapu, (Jakarta: BPK Gunung Mulia, 2004), hlm.93-105

${ }^{6}$ Ibid, hlm. 253

${ }^{7}$ Yonas Siahainenia, Wawancara, Waingapu, Minggu, 12 April 2015

${ }^{8}$ Yosina Siahainenia, Wawancara, Waingapu, Sabtu 11 April 2015.

${ }^{9}$ Yance Mangi, Wawancara, Waingapu, Kamis, 16 April 2015. Beliau adalah salah seorang anak dari bapak Y.B.Mangi tokoh jemaat yang terlibat langsung dalam pembangunan gedung ibadah GKS Waingapu. Pada waktu itu kira-kira ia telah berumur 7 tahun sehingga sudah ikut mengumpulkan pasir dengan menggunakan ember berukuran kecil.

${ }^{10}$ Sekarang sudah tidak lagi demikian karena telah dicat putih seluruhnya oleh koster dalam upaya pemeliharaan gedung.

${ }^{11}$ Frans.A.Supusepa, Wawancara, Senin, 13 April 2015.

${ }^{12}$ Irene Umbu Lolo, Rumah Adat Sumba Dan Kontekstualisasi Rumah Ibadah GKS: Suatu Studi Teologis-Liturgi, (Jakarta: STT Jakarta, 2007), Tesis, hlm.30.

${ }^{13}$ Lona Djanggandewa, Wawancara, Waingapu, senin, 16 Maret 2015.

${ }^{14}$ Irene Umbu Lolo, Opcit,hlm.138

${ }^{15}$ F.D.Wellem, Opcit, hlm.33

${ }^{16}$ Ibid, hlm.34

${ }^{17} \mathrm{Ibid}, \mathrm{hlm} .318$

${ }^{18}$ Oe. H. Kapita, Masyarakat Sumba dan Adat Istiadatnya, (Jakarta: BPK Gunung Mulia, 1996), hlm.36, 212

${ }^{19}$ Nggodu Tunggul, Etika dan Moralitas Dalam Budaya Sumba, (Jakarta: Pro Millenio Center, 2004), hlm. 66

${ }^{20}$ Irene Umbu Lolo, Opcit, hlm.49

${ }^{21} \mathrm{Ibid}, \mathrm{hlm} .50$

${ }^{22}$ Th. van den End, Opcit, hlm.122

${ }^{23}$ Stephen B.Bevans, Model-model Teologi Kontekstual, (Maumere: Penerbit Ledelero, 2002), hlm. 29

${ }^{24}$ Alister.E.McGrath, Spiritualitas Kristen, (Medan: Bina Media Perintis, 2007), hlm.201

${ }^{25}$ Menurut dugaan saya berdasarkan lokasi dimaksud pada masa sekarang, mata air yang muncul dibawah pohon dalam kisah ini bisa jadi adalah sebuah sumur.

${ }^{26}$ Domu Hunggurami, Paulus K.Limu dan Herman Djanggandewa, Wawancara, 9 April 2015. Kisah ini mereka terima dari nenek moyang yang secara lisan diceritakan secara turun-temurun pada generasi yang kemudian.

${ }^{27}$ Yuliana Ata Ambu, Wawancara, Sabtu, 9 Mei 2015. Beliau adalah salah seorang Pendeta GKS Jemaat Payeti. 
${ }^{28}$ Agus M.Hardjana, Religiositas, Agama \& Spiritualitas, (Yogyakarta: Kanisius, 2005), hlm. 67,68

${ }^{29}$ Hikmat Budiman, Lubang Hitam Kebudayaan, (Yogyakarta: Kanisius, 2002), hlm.260, 261

${ }^{30}$ Alister.E.McGrath, Opcit, hlm.202

${ }^{31}$ Herman P.Panda, "Usaha Penyesuaian Liturgi Dalam Budaya Sumba dan Konteks Kepercayaan Marapu",dalam Liturgi Otentik dan Relevan, ed. Bernadus Boli Ujan dan Georg Kirchberger, (Maumere: Penerbit Ledelero, 2006), hlm.156

${ }^{32}$ Binsar Jonathan Pakpahan, Menuju Model-Model Ibadah Yang Membangun Sebuah Telaah Relasi Pertumbuhan Spiritualitas Dan Ibadah Dalam Dunia Postmodern, dalam Spiritualitas Ekologis, ed. Robynson Butarbutar, dkk (Jakarta: Institut Darma Mahardika, 2014), hlm.139

\section{DAFTAR PUSTAKA}

Bevans.Stephen B. 2002. Model-model Teologi Kontekstual, Maumere: Penerbit Ledelero.

Budiman.Hikmat, 2002. Lubang Hitam Kebudayaan, Yogyakarta: Kanisius.

End, Th. van, 1996. Sumber-Sumber Zending Tentang Sejarah Gereja Kristen Sumba 1859 - 1972, Jakarta, BPK Gunung Mulia.

Hardjana.Agus M. 2005. Religiositas, Agama \& Spiritualitas, Yogyakarta: Kanisius.

Kapita, Oe. H, 1976. Masyarakat Sumba Dan Adat Istiadatnya, Jakarta: BPK Gunung Mulia.

Lolo.Irene Umbu, 2007. Rumah Adat Sumba Dan Kontekstualisasi Rumah Ibadah GKS : Suatu Studi Teologis-Liturgi, Jakarta : STT Jakarta.

McGrath Alister.E., 2007. Spiritualitas Kristen,Medan: Bina Media Perintis.

Pakpahan.Binsar Jonathan, 2014. Menuju Model-Model Ibadah Yang Membangun

Sebuah Telaah Relasi Pertumbuhan Spiritualitas Dan Ibadah Dalam

Dunia Postmodern, dalam Spiritualitas Ekologis, ed. Robynson Butarbutar, dkk, Jakarta, Institut Darma Mahardika.

Panda.Herman P. 2006. Usaha Penyesuaian Liturgi Dalam Budaya Sumba dan Konteks Kepercayaan Marapu, dalam Liturgi Otentik dan Relevan, ed. Bernadus Boli Ujan dan Georg Kirchberger, Maumere: Penerbit Ledelero.

Prior.John Mansford, 2004. Berdiri di Ambang Batas, Maumere: Penerbit Ledelero.

Tunggul, Nggodu, 2004. Etika dan Moralitas Dalam Budaya Sumba, Pro Millenio Center.

Wellem F.D., 2004. Injil Dan Marapu, Jakarta: BPK Gunung Mulia. 